\title{
000599
}

\section{INTERIM ACTION RECORD OF DECISION REMEDIAL ALTERNATIVE SELECTION}

Metallurgical Laboratory Hazardous Waste Management Facility Operable Unit

\author{
Savannah River Site \\ Aiken County, South Carolina
}

Prepared by:

U.S. Department of Energy

Savannah River Field Office

Aiken, South Carolina 
This document was prepared in conjunction with work accomplished under Contract No. DE-AC09-89SR18035 with the U.S. Department of Energy.

\section{DISCLAIMER}

This report was prepared as an account of work sponsored by an agency of the United States Government. Neither the United States Government nor any agency thereof, nor any of their employees, makes any warranty, express or implied, or assumes any legal liability or responsibility for the accuracy, completeness, or usefulness of any information, apparatus, product or process disclosed, or represents that its use would not infringe privately owned rights. Reference herein to any specific commercial product, process or service by trade name, trademark, manufacturer, or otherwise does not necessarily constitute or imply its endorsement, recommendation, or favoring by the United States Government or any agency thereof. The views and opinions of authors expressed herein do not necessarily state or reflect those of the United States Government or any agency thereof.

This report has been reproduced directly from the best available copy.

Available for sale to the public, in paper, from: U.S. Department of Commerce, National Technical Information Service, 5285 Port Royal Road, Springfield, VA 22161, phone: (800) 553-6847, fax: (703) 605-6900

email: orders@ntis.fedworld.gov

online ordering: http://www.ntis.gov/support/index.html

Available electronically at http://www.doe.gov/bridge

Available for a processing fee to U.S. Department of Energy and its contractors, in paper, from: U.S. Department of Energy, Office of Scientific and Technical Information, P.O. Box 62, Oak Ridge, TN 37831-0062, \&nbsp;phone: (865 ) 576-8401, \&nbsp;fax: (865) 576-5728,

email: reportseadonis.osti.gov 


\section{DECLARATION FOR THE INTERIM ACTION RECORD OF DECISION}

\section{Site Name and Location}

Metallurgical Laboratory Hazardous Waste Management Facility (HWMF) Operable Unit Savannah River Site

Aiken County, South Carolina

Appendix C of the draft Federal Facility Agreement (FFA) refers to this operable unit as the 723-A Met Lab Basin/Carolina Bay (Building Number 904-110G).

\section{Statement of Basis and Purpose}

This document presents the selected interim remedial action for the Metallurgical Laboratory HWMF Operable Unit at the Savannah River Site (SRS), which was developed in accordance with the Comprehensive Environmental Response, Compensation and Liability Act of 1980 (CERCLA), as amended by the Superfund Amendments and Reauthorization Act of 1986 (SARA), and to the extent practicable, the National Oil and Hazardous Substances Pollution Contingency Plan (NCP). This decision is based on the administrative record file for this specific operable unit.

\section{Description of the Selected Remedy}

The interim action selected remedy involves the placement of all contaminated materials under a low permeability soil cap. This remedy prevents physical exposure to contaminants and mitigates further migration of contaminants to the groundwater by minimizing a liquid medium pathway (rainwater percolation) for transport. 
A risk evaluation will be developed for the Metallurgical Laboratory HWMF after final closure of the basin. A risk assessment of the Carolina Bay has been developed and is currently under review by the State and EPA. Both risk assessments will be addressed in the final Record of Decision (ROD).

The major components of the interim action remedy include:

- Sampling of accumulated rainwater in the basin;

- Treating and releasing excess water to a NPDES permitted outfall;

- Excavation of the process sewer line and associated soils and placement in the basin;

- Compacting of basin and process sewer line materials;

- Installing a low permeability cap over the basin.

\section{Declaration Statement}

The interim action is hereby selected by mutual agreement of the U.S. Department of Energy and the U.S. Environmental Protection Agency. This interim action is protective of human health and the environment, complies with Federal and State applicable or relevant and appropriate requirements (ARARs) for this limited-scope action, and is cost-effective. This action is interim and is not intended to utilize permanent solutions and alternative treatment (or resource recovery) technologies to the maximum extent practicable for the Metallurgical Laboratory HWMF Operable Unit. Because this action does not constitute the final remedy for the Metallurgical Laboratory HWMF Operable Unit, the statutory preference for remedies that employ treatment that reduces toxicity, mobility, or volume as a principal element will be fully addressed by the final response action. Subsequent actions 
are planned to address fully the threats posed by the conditions at the Metallurgical Laboratory HWMF Operable Unit. Because this remedy may result in hazardous substances remaining in the operable unit above health-based levels, a five-year review will be conducted to ensure that the remedy continues to provide adequate protection of human health and the environment after commencement of the remedial action. Because this is an interim action ROD, review of this operable unit and of this remedy will be conducted by the Environmental Protection Agency (EPA) until a final remedial alternative for the Metallurgical Laboratory HWMF Operable Unit is selected.

$\frac{6 / 25 / 92}{\text { Date }}$

JUN 29 1999

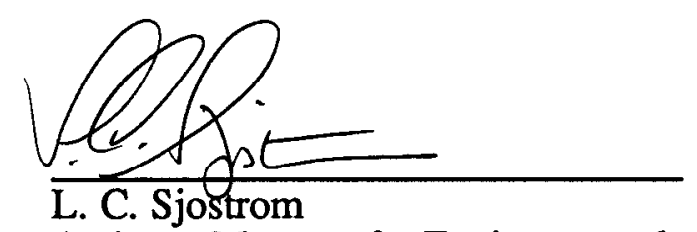
Assistant Manager for Environmental Restoration and Waste Management U.S. Department of Energy

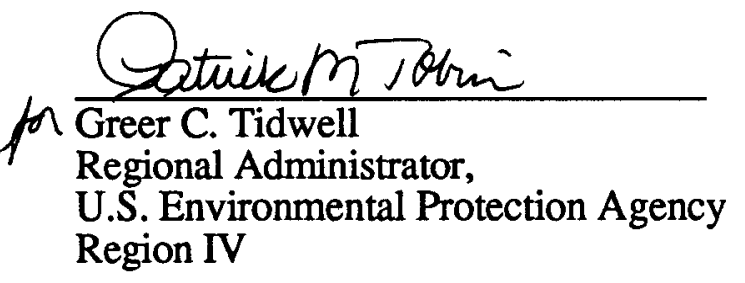




\title{
SUMMARY OF INTERIM ACTION REMEDIAL ALTERNATIVE SELECTION
}

Metallurgical Laboratory Hazardous Waste Management Facility Operable Unit

\author{
Savannah River Site \\ Aiken County, South Carolina
}

Prepared by:

U.S. Department of Energy

Savannah River Field Office

Aiken, South Carolina 
DECISION SUMMARY

TABLE OF CONTENTS

Section

Page

I. Site and Operable Unit Names, Locations, and Descriptions

II. Operable Unit History and Compliance History

III. Highlights of Community Participation 7

IV. Scope and Role of Operable Unit within the Site Strategy 7

V. Summary of Operable Unit Characteristics 7

VI. Summary of Operable Unit Risks 9

$\begin{array}{ll}\text { VII. Description of Alternatives } & 11\end{array}$

VIII. Summary of Comparative Analysis of Alternatives 20

IX. Selected Remedy 26

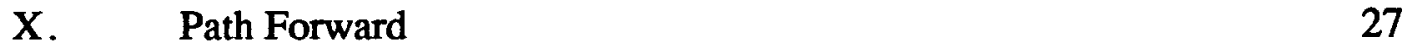

$\begin{array}{ll}\text { XI. Statutory Determination } & 27\end{array}$

\section{Appendices}
A. References for Development of ROD Format
B. Responsiveness Summary 


\section{Site and Operable Unit Names, Locations, and Descriptions}

The Savannah River Site (SRS) occupies approximately 300 square miles adjacent to the Savannah River, principally in Aiken and Barnwell Counties of South Carolina (Figure 1). SRS is a secured facility with no permanent residents. The site is approximately 25 miles southeast of Augusta, Georgia, and 20 miles south of Aiken, South Carolina. The average population density in the counties surrounding SRS ranges from 23-560 people per square mile with the largest concentration in the Augusta, Georgia, metropolitan area. Based on 1980 census data (1990 data not available), the population within a 50 -mile $(80 \mathrm{~km})$ radius of SRS is approximately 555,100 .

SRS is owned by the United States Department of Energy (DOE). Westinghouse Savannah River Company (WSRC) is a co-operator, providing management and operation services for DOE. SRS produces tritium, plutonium, and other special nuclear materials for national defense. The site also provides nuclear materials for the space program, and conducts medical, industrial, and research efforts. The A/M Area, located in the northwest portion of the SRS (Figure 1), contains nuclear fuel fabrication buildings, office buildings, and research areas.

The Metallurgical Laboratory HWMF is a source-specific operable unit within the A/M Area Fundamental Study Area. The Metallurgical Laboratory HWMF includes an abandoned portion of a process sewer line, a seepage basin, a drainage outfall, and a Carolina bay as shown in Figure 2. The nearest plant boundary is located approximately three-fourths of a mile to the northwest of this operable unit. 


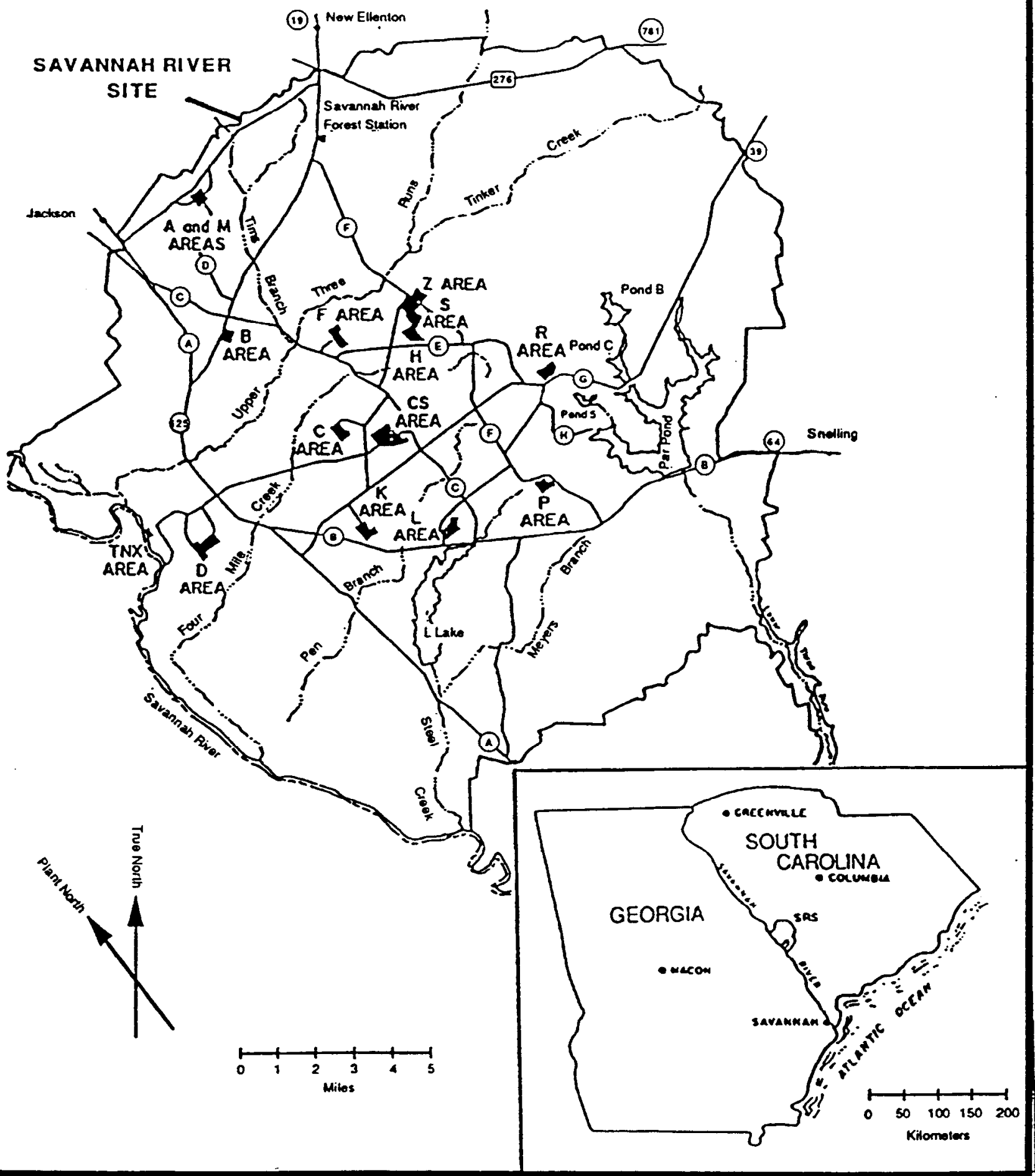

Figure 1 Location of the Savannah River Site (SRS)

(Source: Modified from the Savannah River Environmental Report, 1990) 


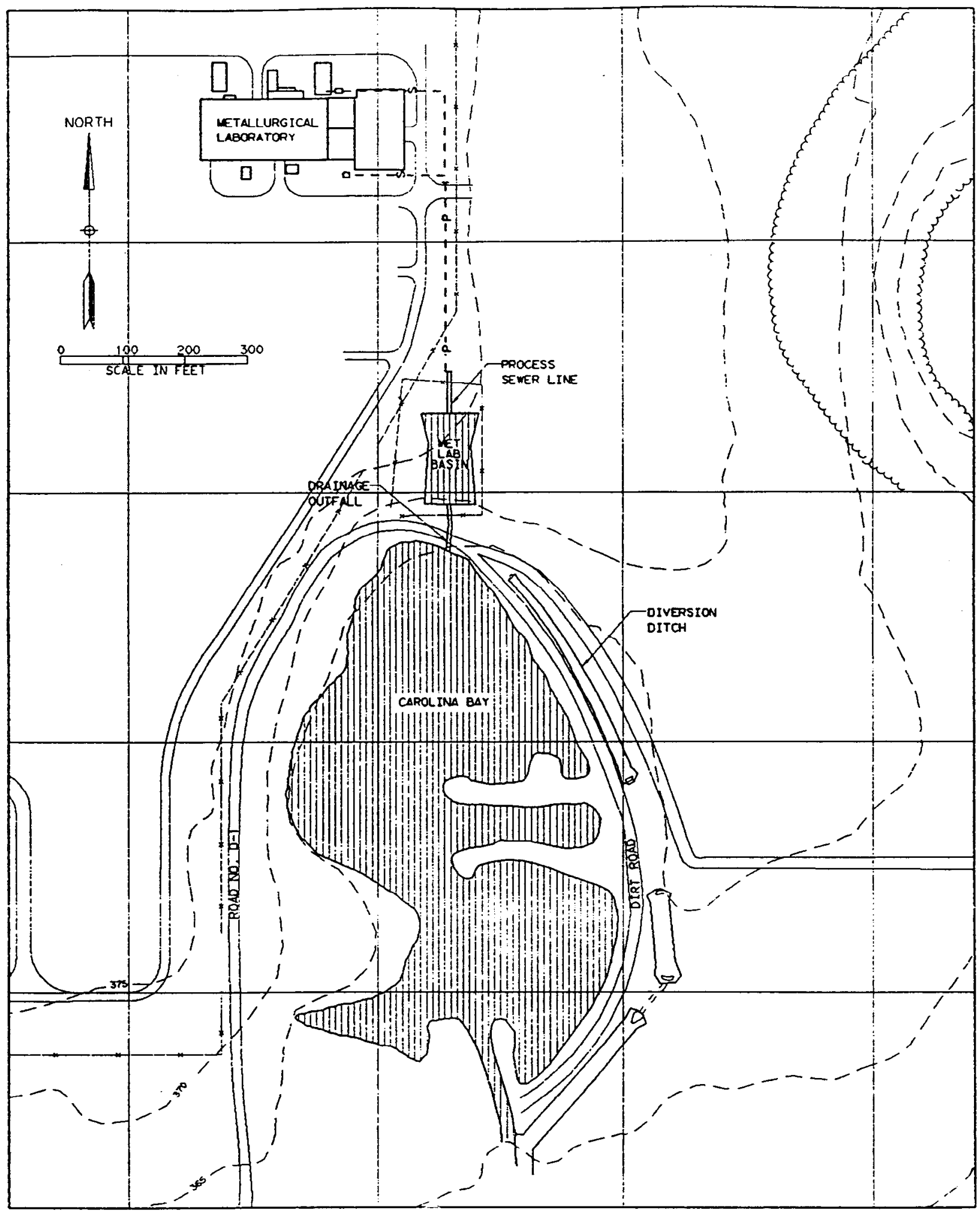

Figure 2 Metallurgical Laboratory HWMF (Source: Metallurgical Laboratory HWMF Part B Post-Closure Permit Application, 1991) 


\section{Operable Unit History and Compliance History}

\section{Operable Unit History}

The Metallurgical Laboratory HWMF began receiving effluent from the Savannah River Laboratory (SRL) Equipment Engineering Division Metallurgical Laboratory (Building 723-A) in 1956. The effluent consisted primarily of noncontact cooling water (water which does not contact process operations) and small quantities of laboratory rinse water containing hazardous substances. The release of these substances to the Metallurgical Laboratory HWMF was discontinued in 1983. Since 1983, hazardous wastes from the Metallurgical Laboratory have been stored at a treatment, storage, and disposal (TSD) facility within SRS awaiting final treatment and disposal in accordance with South Carolina Department of Health and Environmental Control (SCDHEC) regulations. Discharges to the basin during the period from 1983 to November 8,1985 , consisted of non-hazardous effluent. All flow to the Metallurgical Laboratory Basin was terminated on November 8, 1985, when the process sewer line was plugged. The Metallurgical Laboratory nonhazardous effluent was rerouted to a National Pollutant Discharge Elimination System (NPDES) permitted outfall at SRS.

The Metallurgical Laboratory was used for corrosion testing on stainless steels and nickelbased alloys. This testing required degreasing and cleaning metal parts, etching sample identification information on the parts, and photographing the samples. Cooling water was used to condense nitric acid solution generated from corrosion testing. Small quantities of laboratory rinse water were generated from washing laboratory glassware.

Degreasing involved immersing metal parts in solvents to remove dirt and grease. Solvents used for degreasing metal samples included acetone, 1,1,1-trichloroethane, 
trichloroethylene, and tetrachloromethane (carbon tetrachloride). When the solvents became saturated with grease and were no longer usable, they were discharged to the HWMF in quantities of less than 0.25 gallons at a time.

Potassium cyanide, sodium cyanide, and hydrofluoric acids were used as etchants for preparing samples for metallographic evaluation. These chemicals were used and discharged intermittently in minute quantities $(1$ to $50 \mathrm{ml}$ ) to the HWMF over its operational history.

Laboratory operations included cleaning of stainless steel fill and capillary tubing. The waste from this operation, which contained hydrofluoric acid, acetic acid, and fluoride salts, was discharged intermittently in small quantities to the HWMF over its operational history.

Effluent was discharged intermittently from the Metallurgical Laboratory to the Metallurgical Laboratory Basin via an 8-inch diameter, vitrified clay process sewer line buried approximately 6 feet underground. A portion of the process sewer was capped and abandoned in place on November 8, 1985. Non-contact cooling water was discharged at a rate of approximately 1000 gallons per day (gpd) throughout the operating period of the basin $(1956$ to November 8,1985$)$. Rinse water from photographic processes and various laboratory operations, including cleaning metal samples and laboratory equipment, was discharged at a rate of approximately $125 \mathrm{gpd}$. No radioactive materials were known to have been discharged to the HWMF.

During periods of heavy rainfall, wastewater and surface water overflowed a drainage outfall at the Metallurgical Laboratory Basin into the adjacent Carolina Bay. The basin outfall consisted of a buried pipe beneath the roadway and a drainage ditch from the 
roadway into the Carolina Bay. The overflow pipe was excavated after discharges to the basin were halted in 1985. The Carolina Bay currently receives stormwater runoff from the spare machinery storage area, and surface runoff and discharge of cooling water from a coal-fired power plant (Building 784-A). The maximum volume of effluent discharged from the power plant was approximately $300,000 \mathrm{gpd}$, but is presently much less.

\section{Compliance History}

On September 24, 1985, the Natural Resources Defense Council (NRDC) and others filed a complaint against DOE concerning the Metallurgical Laboratory Basin and neighboring Carolina Bay. The associated lawsuit resulted in a Consent Decree in June 1988 which mandated that the Metallurgical Laboratory HWMF and associated Carolina Bay were subject to RCRA (Docket \#CVAC1:85-2583-6, U.S. District Court, District of South Carolina, Aiken Division). The basin and sewer line portions of the Metallurgical Laboratory HWMF are being closed under interim status regulations South Carolina Hazardous Waste Management Regulation (SCHWMR) R.61-79.265 and will be permitted as a hazardous waste management facility by a Post-Closure Care, Part B Permit SCHWMR R.61-79.264.

A RCRA closure plan for the basin and sewer line portions of the Metallurgical Laboratory HWMF was submitted to, and approved by, SCDHEC in June 1991. The intent of the closure plan is to ensure the basin and sewer line portions of the Metallurgical Laboratory HWMF will be closed in a manner that controls, minimizes, or eliminates (to the extent necessary to prevent threats to human health and the environment) post-closure migration of hazardous constituents and decomposition products to the vadose zone, groundwater, surface waters, or atmosphere. 
The Metallurgical Laboratory HWMF became subject to CERCLA requirements as a result of SRS being placed on the National Priorities List (NPL) in December 1989. Due to the multiple source areas in close proximity and the co-mingling of contaminants emanating from these source areas, the A/M Area has been designated a Fundamental Study Area. The purpose of this designation is to facilitate the coordination of remedy selection decisions for the operable units in this area. The Metallurgical Laboratory HWMF has been designated as a source-specific operable unit within the A/M Area Fundamental Study Area.

\section{Highlights of Community Participation}

No comments were received during the public review period.

\section{Scope and Role of Operable Unit within the Site Strategy}

The purpose of this interim action for the Metallurgical Laboratory HWMF Operable Unit is to minimize migration of contaminants to groundwater from the Metallurgical Laboratory Basin sediments and sediments associated with the process sewer line while risk assessment activities for the Carolina Bay are being planned and conducted.

The interim remedial action will be consistent with any planned future actions for this operable unit.

The groundwater associated with the Metallurgical Laboratory is addressed in the ROD for the A/M Area Groundwater Operable Unit.

\section{Summary of Operable Unit Characteristics}

Various sampling activities conducted at the Metallurgical Laboratory HWMF since November 1985, when its use was discontinued, indicate that contamination is present in 
groundwater, basin surface water, soil, and basin sediments. A characterization program for the Metallurgical Laboratory Basin and associated process sewer line was conducted from September 1984 to January 1985. A total of 70 sediment samples were analyzed, with 56 collected in and around the basin and 14 collected at joints in the process sewer pipeline. All 70 samples were analyzed for metals, inorganic ions, $\mathrm{pH}$, specific conductance, and volatile solids. A total of seven soil borings were taken from beneath and around the basin. Soil and sludge samples to a depth of 20 feet were collected at three locations within the basin and analyzed. Soil outside the basin was collected to a depth of 25 feet at four locations. The samples were analyzed for organic solvents, inorganic compounds, and metals.

Analytical results indicate that no significant organic contamination exists in any of the basin sediments sampled. Analytical results for inorganics indicate elevated concentration levels of sulfate and nitrate in the 5 to 8 foot-depth samples taken beneath the basin. Cyanide was detected only in the top layer of the basin sediments at concentrations slightly above background. Slightly elevated cyanide concentrations were detected along the process sewer line. Metals were detected; however, the results of the EP toxicity test (the approved leach test at the time these samples were taken) for the process sewer line and basin soils showed the concentrations of metals were all substantially below the EP concentration criteria.

The Metallurgical Laboratory HWMF is located in the general vicinity of a documented groundwater plume of volatile organic contamination in the A/M Area. The groundwater monitoring well network around the HWMF consists of 18 wells screened in various hydrologic intervals beneath the unit. The wells are monitored on a quarterly basis. Chlorinated solvents, specifically trichloroethylene and tetrachloroethylene, have been 
measured at levels above the primary drinking water standards in both downgradient and upgradient wells.

A preliminary characterization of the Carolina Bay was performed in 1988 to determine whether constituents had migrated from the Metallurgical Laboratory Basin. A baseline risk assessment for the Carolina Bay is currently being conducted. The potential remedial resolution for the bay will be contained in the final ROD.

\section{Summary of Operable Unit Risks}

A risk evaluation will be performed after closure of the Metallurgical Laboratory Basin and characterization of the Carolina Bay. The previous risk analysis, performed in 1985 for the Metallurgical Laboratory HWMF, was used in the development of closure alternatives. The results of the previous risk analysis, in addition to available closure and post-closure data, will be utilized to evaluate potential post-closure risks.

The chemicals that were evaluated in the 1985 risk assessment work included: radium, chromium, lead, mercury, 1,1,1-trichloroethane, tetrachloromethane, tetrachloroethylene, and trichloroethylene.

Risk analysis work conducted in 1985 to evaluate closure options for the Metallurgical Laboratory HWMF, indicated that contamination was present in groundwater, basin surface water, soil, and basin sediments. However, the current risk evaluation program will be based on available post-closure information for groundwater, surface water, soil, and sediments. Furthermore, the risk evaluation work will be conducted in two parts based on source-specific units within the Fundamental Study Area. 
The preferred alternative for closure of the Metallurgical Laboratory HWMF involves no waste removal, excavation of the process sewer line and associated contaminated sediments and placement in the basin, basin closure (capping), and characterization of the associated Carolina Bay. Because the basin will be capped, this closure will minimize any potential exposure through surface pathways (soil, sediment, and air). A risk evaluation will be performed to address these post-closure surface pathways.

Subsurface contamination resulting from the Metallurgical Laboratory HWMF is currently being addressed as part of the on-going A/M Area Groundwater Corrective Action Program. Risks associated with the Metallurgical Laboratory HWMF subsurface pathways (vadose zone and groundwater) are a subset of the risks for the entire A/M Area Groundwater Operable Unit. Therefore, the Metallurgical Laboratory HWMF subsurface unit risks will be addressed as part of a separate baseline risk assessment for the A/M Area Groundwater Operable Unit.

Additional analyses of the contamination associated with the Carolina Bay are being considered as part of a risk assessment currently being conducted. This will result in a complete characterization of the unit.

The potential pathways for human exposure are through surface, subsurface, and atmospheric transport of contaminants. The extent to which remediation and closure activities will eliminate surface and associated atmospheric pathways will be addressed in the Metallurgical Laboratory HWMF risk evaluation. Subsurface exposure pathways are to be evaluated in the separate A/M Area Groundwater risk assessment.

It is expected that the risk evaluation will show reduced or no potential for risk to human health and the environment. However, the potential for human exposure does exist. 
The primary potential for ecological risks is through contamination associated with the Carolina Bay. Further assessment of these risks are to be conducted in the future.

Potential risks associated with the post-closure conditions of the basin and associated process sewer line will be evaluated in the Metallurgical Laboratory HWMF risk evaluation and the A/M Area Groundwater risk assessment.

\section{Description of Alternatives}

The following sections include brief descriptions of the remedial alternatives developed in 1985 for the Metallurgical Laboratory HWMF. Because the risk assessment for the Carolina Bay is not completed, the alternatives were based on remediation of the process sewer line and basin portions of the Metallurgical Laboratory HWMF only. Final plans for the Metallurgical Laboratory HWMF will address all portions of the HWMF, including the Carolina Bay. In accordance with the NCP, the No Action Alternative was set forth as a baseline for comparison. The alternatives originally developed included:

\section{Alternative 1}

No Action

\section{Alternative 2}

No Waste Removal, No Action for Process Sewer Line, Basin Closure, and Evaluation of the Carolina Bay

\section{Alternative 3}

Waste Removal, No Action for Process Sewer Line, Basin Closure, and Evaluation of the Carolina Bay

Alternative 4 
No Waste Removal, Excavation of Process Sewer Line, Basin Closure, and Evaluation of the Carolina Bay

Alternative 4 was selected in 1985 as the preferred alternative. Closure activities, in accordance with an approved RCRA Closure Plan, began in 1991 and are still in progress. The remainder of this section contains a description of each of the four alternatives as they were developed and considered in 1985.

\section{Alternative 1: No Action}

Under the No Action Alternative, soils near the process sewer line, the sediment in the Metallurgical Laboratory Basin and the soils in the Carolina Bay would remain in place. The groundwater monitoring program would continue for a 30 -year period and any additional time required to remediate the A/M Area Groundwater

Treatment Components. Under this alternative, the Metallurgical Laboratory Basin sediments, the soils near the process sewer line, and the soils in the Carolina Bay would be left in place and no remedial efforts would be conducted to prevent the leaching of chemical residuals to the groundwater.

Engineering Controls. The groundwater would be monitored quarterly for one year, then annually for the next 29 years. Site maintenance, including inspection of the existing exclusion fence, would be implemented for the entire 30-year period, and any additional time required to remediate the $\mathrm{A} / \mathrm{M}$ Area groundwater.

Institutional Controls. The Metallurgical Laboratory HWMF is located in an area accessible only by roads that are controlled continuously by manned barricades within SRS. The HWMF is located immediately outside the A-Area operating fence, but within the fenced 
area of the SRS. The basin area is periodically patrolled by security personnel and is surrounded by an exclusion fence. SRS must also inspect all HWMFs in accordance with RCRA requirements. Other institutional controls would include submission of applicable survey plats containing the information specified in SCHWMR R.61-79.264.119 to the Aiken County, South Carolina zoning authority and to SCDHEC. In addition, the plats would be recorded with the Aiken County Registrar of Deeds and, as required by SCHWMR R.61-79.265.120, notices would be placed with the federal government's deed to the SRS land.

Quantity of Waste. No waste would be removed or treated under the No Action Alternative. The amount of contaminated sediment remaining in the basin would be approximately 450 cubic yards. The amount of rainwater in the basin would fluctuate, but would be approximately 30,000 gallons (based on a one foot depth).

Implementation Requirements. The No Action Alternative requires implementation of the aforementioned institutional controls.

Estimated Construction and Operation and Maintenance (O\&M) Costs. Additional monitoring wells would not be installed under the No Action Alternative. Costs for this alternative were originally estimated to be:

- Capital Cost $\$$

- Annual O\&M Costs $\$ 20,000$

ARARs Associated with the Considered Alternatives. The alternative would not be protective of human health due to continued migration of chemical residuals from the basin to groundwater. The 1985 risk assessment for the Metallurgical Laboratory HWMF details the risks involved in the leaching of the hazardous constituents to groundwater. 
Alternative 2: No Waste Removal, No Action for Process Sewer Line Basin Closure, and Evaluation of the Carolina Bay

Alternative 2 consists of sampling the accumulated rainwater in the basin and, pending confirmation of allowable chemical residual levels, release of this water to the NPDESpermitted FS-002 Outfall at Upper Three Runs Creek. The basin would then be capped with a low permeability cap. In addition, the Carolina Bay would be investigated to determine if remedial action is necessary. No remedial action would be implemented for the process sewer line and associated soils.

Treatment Components. No treatment would be implemented under Alternative 2 .

Engineering Controls. If the basin water sampled indicates that water quality standards specified in the NPDES permit would be exceeded at the outfall, the effluent would not be discharged. The water would be handled as a hazardous waste under SCHWMR R.61-79 or treated to meet the NPDES permit. The basin would then be filled with clean soils, and a low permeability cap would be constructed on top of the clean fill. The cap would consist of a low permeability compacted clay layer, a geotextile fabric, and another soil layer consisting of common fill and topsoil. The topsoil would be seeded to minimize erosion. The cap would serve as a barrier to infiltration of precipitation, which in turn would limit the mobility of subsurface chemical residuals. This alternative would significantly decrease the leaching of constituents to the groundwater from the basin. Source areas associated with the process sewer line would not be addressed under this alternative.

Institutional Controls. As discussed under Alternative 1, access to the Metallurgical Laboratory Basin would be restricted by the existing exclusion fence which surrounds the immediate area of the basin. Following closure, the appropriate plats would be submitted to regulatory agencies for deed restrictions as outlined in SCHWMR R.61-79.264.119. 
Quantity of Waste. The only waste that would be involved in the implementation of Alternative 2 would be the accumulated rainwater in the basin, should any exist, if sampling during closure indicated elevated chemical levels. Basin levels fluctuate due to precipitation, and could evaporate altogether. The actual quantity of rainwater would be assessed at the time of remediation, but is expected to be approximately 30,000 gallons, based on one foot depth. The waste sediments remaining in the basin would be approximately 450 cubic yards.

Implementation Requirements. Alternative 2 would not pose any significant construction or operational difficulties, although periodic inspections of the cap would be necessary. A NPDES permit modification would be required for the outfall to Upper Three Runs Creek. It was estimated that Alternative 2 would take approximately four months to implement.

Estimated Construction and Operation and Maintenance Costs. Costs for this alternative were originally estimated to be:

- Capital Cost $\$ 1,000,000$

- Annual O\&M Costs $\$ 20,000$ ARARs Associated with the Considered Alternative. Federal RCRA regulations would be applicable, and the cap design would have to meet RCRA equivalent performance standards (SCHWMR R.61-79.264.310). A NPDES permit modification would be required for the outfall to Upper Three Runs Creek. 


\section{Alternative 3: Waste Removal, No Action for Process Sewer Line, Basin Closure, and Evaluation of the Carolina Bay}

Alternative 3 consists of sampling of the basin rainwater (if any), releasing this rainwater to NPDES permitted FS-002 Outfall at Upper Three Runs Creek, removing approximately 450 cubic yards of basin sediment, backfilling the basin with clean fill, and continuing groundwater monitoring. In addition, the Carolina Bay would be investigated to evaluate what remedial actions, if any, are applicable. No remedial action would be implemented for the process sewer line and associated soils.

Treatment Components. No treatment would be implemented under Alternative 3.

Engineering Controls. As with Alternative 2, the basin liquid would be sampled before discharge to Upper Three Runs Creek. Constituent concentrations exceeding the quality standards set forth in the NPDES permit would be handled as a hazardous waste under SCHWMR R.61-79 or treated to meet the NPDES permit standards. Approximately 450 cubic yards of the sediment at the bottom of the basin would be excavated and transported to a TSD facility within the SRS. The excavation would remove nearly all remaining waste source materials. The basin would then be backfilled with soil, regraded to original land contours, and seeded. Because waste would be removed, a low permeability cap would not be required.

Institutional Controls. Because no contamination would be left in the basin, there would be no institutional control requirements. The existing exclusion fence surrounding the Metallurgical Laboratory Basin would remain. 
Quantity of Waste. This waste removal option would include excavation of all remaining source materials (approximately 450 cubic yards). The amount of basin rainwater requiring discharge would be approximately 30,000 gallons (based on a one foot depth) depending on precipitation prior to remediation.

Implementation Requirements. Implementation would require a potential NPDES permit modification for the outfall. No construction or maintenance difficulties are anticipated in sediment removal. However, approximately 20 truck loads of hazardous materials would have to be transported to a TSD facility within SRS. It was estimated that implementation of Alternative 3 would take approximately seven months.

Estimated Construction and Operation and Maintenance Costs. Costs for this alternative were originally estimated to be:

- Capital Cost

- Annual O\&M Costs
$\$ 1,000,000$

$\$ 20,000$

The capital cost reflected values associated with waste removal and temporary storage at the TSD facility on the SRS property. These costs did not include final disposal at a permanent facility.

ARARs Associated with the Considered Alternative. ARARs for the liquid discharge portion of this alternative would include a NPDES permit modification. Department of Transportation (DOT) regulations for shipment of hazardous substances specified in 49 CFR $\S \S 100-177$ are applicable if hazardous wastes are transported off site. Disposal of the contaminated sediments would be regulated under RCRA and as specified in SCHWMR R.61-79 Part 264. 
Alternative 4: No Waste Removal. Excavation of Process Sewer Line, Basin Closure, and Evaluation of the Carolina Bay

Alternative 4 is a modification of Alternative 2. It included excavation of the process sewer line and associated soil materials and placement of the materials within the basin prior to capping.

Treatment Components. No treatment would be implemented under Alternative 4 .

Engineering Controls. As in Alternative 2, the basin liquid rainwater would be sampled and if the constituent concentrations exceed the water quality standards required by the NPDES permit, the water would be handled as a hazardous waste under SCHWMR R.6179 or treated to meet the NPDES permit. Otherwise, the water would be discharged through the NPDES permitted FS-002 outfall at Upper Three Runs Creek.

The process sewer line and associated sediments would be excavated and placed inside the basin prior to installation of a low permeability cap as presented in Figure 3. The cap would serve as a barrier to infiltration of precipitation, which in turn would limit the mobility of subsurface chemical residuals.

Institutional Controls. The existing exclusion fence would remain to restrict access. In addition, the deed restrictions and institutional controls action required by SCHWMR R.61-79.264.119 would be implemented.

Quantity of Waste. The quantity of rainwater in the basin could range from 0 gallons to approximately 100,000 gallons, depending on precipitation. Based on a one foot depth in e basin, the rainwater would total 30,000 gallons. The sediments in the bottom of the in total approximately 450 cubic yards. 


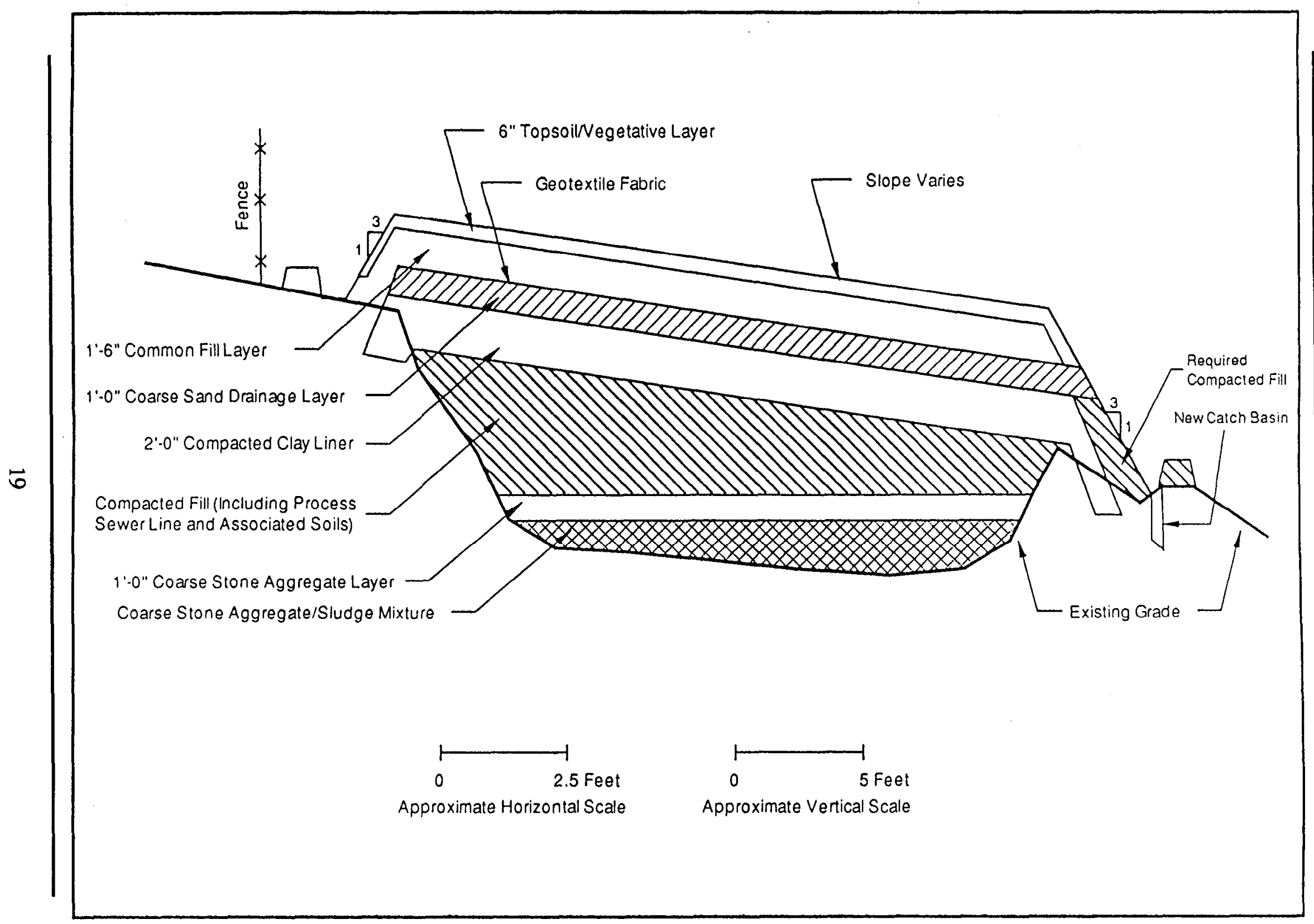

Figure 3 Cross-Sectional Diagram of the Metallurgical Laboratory HWMF Cap 
Implementation Requirements. There were no implementation concerns for the liquid removal or for the installation or maintenance of the cap. It was estimated that implementation of Alternative 4 would take approximately seven months.

Estimated Construction and Operation and Maintenance Costs. Costs for this alternative were originally estimated to be:

- $\quad$ Capital Cost

$\$ 1,400,000$

- Annual O\&M Costs

$\$ 20,000$

ARARs Associated with the Considered Alternative. One ARAR for Alternative 4 would be a NPDES permit modification for discharge of the basin rainwater to FS-002 outfall at Upper Three Runs Creek. Another ARAR would include SCHWMR R.61-79.265 for RCRA equivalent performance standards for the cap design. The equivalent performance standards include the following:

- Provide long-term minimization of migration of contaminants.

- $\quad$ Function with minimum maintenance.

- Promote drainage and minimize erosion or abrasion of the cover.

- Accommodate settling and subsidence to maintain cover integrity.

- Have a permeability less than that of natural subsurface soils.

\section{Summary of Comparative Analysis of Alternatives}

The NCP (40 CFR $\S 300.430$ (e)(9)) sets forth nine evaluation criteria that provide the basis for evaluating alternatives and subsequent selection of a remedy. The criteria are: 
- Overall protection of human health and the environment

- $\quad$ Compliance with ARARs

- $\quad$ Long-term effectiveness and permanence

- Reductions of toxicity, mobility or volume through treatment

- $\quad$ Short-term effectiveness

- Implementability

- Cost

- State acceptance

- Community acceptance

The four alternatives described in Section VII are compared in this section using these nine evaluation criteria.

Overall Protection of Human Health and the Environment. Alternative 1, the No Action Alternative, would not be protective of, and would offer no reduction in risk to human health and the environment. The No Action Alternative would allow continued transport of organic and inorganic constituents within the basin sediments to groundwater.

Alternative 2, the No Waste Removal, No Action for Process Sewer Line, Basin Closure, and Evaluation of the Carolina Bay Alternative would provide protection by isolating chemical residuals within the basin beneath a low permeability closure cap. The cap would minimize the potential for chemical residuals to enter the groundwater and would prevent direct contact by environmental receptors (e.g., vegetation: plant and tree roots) with constituents in the basin. However, this alternative could continue to allow transport of 
organic and inorganic constituents from contaminated sediments associated with the sewer line to the groundwater.

In Alternative 3, the Waste Removal, No Action for Process Sewer Line, Basin Closure, and Evaluation of the Carolina Bay Alternative, chemical residuals would be removed from the basin, eliminating risks associated with the basin sediments. The constituents and their associated risks would be moved to another location. The risks would still have to be addressed by ensuring that the new location is a RCRA regulated TSD facility. In addition, Alternative 3 does not address the possible transport of constituents from the process sewer line and surrounding soils to the groundwater.

In Alternative 4, the No Waste Removal, Excavation of Process Sewer Line, Basin Closure, and Evaluation of the Carolina Bay Alternative, chemical residuals within the basin and those associated with the process sewer line would be isolated beneath a low permeability cap. This alternative would minimize the migration of constituents from sediments into the groundwater, both in the basin and associated with the sewer line.

Compliance with Applicable or Relevant and Appropriate Requirements (ARARs). No state promulgated chemical-specific ARARs exist for chemical residuals in soils. However, Alternative 1 would allow continued migration of chemicals to groundwater and potentially exceed promulgated groundwater standards and pose risks to human health and the environment.

The chemical-specific ARARs for Alternative 2 would include a NPDES permit for discharge of basin rainwater and controlling incidental exposure to chemical residuals at the Metallurgical Laboratory HWMF. A particular action-specific ARAR for Alternative 2 is the regulations regarding capping, SCHWMR R.61-79.265. The cap for this alternative 
must be designed and installed according to RCRA requirements to comply with the actionspecific ARAR. Capping would help achieve groundwater chemical-specific requirements because it would minimize leaching of basin chemical residuals to groundwater. However, the process sewer line and associated soils could continue leaching constituents to the groundwater.

As with Alternative 2, Alternative 3 would allow continued leaching of chemical residuals to the groundwater from soils associated with the sewer line. Additionally, the removed materials must be stored at a storage facility designed to meet the TSD facility requirements set forth under SCHWMR R.61-79.264 and require a NPDES permit modification.

Alternative 4 would meet all ARARs. This altemative would minimize leaching of chemical residuals to groundwater and would meet all requirements for capping SCHWMR R.6179.265 and NPDES discharge.

Long-term Effectiveness and Permanence. The No Action Alternative (1) is not effective over the long term and is not a permanent solution because the chemical residuals may continue to leach to groundwater. Alternatives 2 and 3 would be effective in addressing basin sediments, but would not be effective with respect to the sewer line and associated soils. Alternative 4 would be effective for known risks at the site, both for sediments in the basin and soils associated with the sewer line. Cap maintenance for Alternative 4 would continue for at least 30 years (the post-closure case period), with extension of this period reviewed every five years.

Reduction of Toxicity Mobility or Volume. Alternative 1 would not reduce the toxicity, mobility, or volume of contaminants at the Metallurgical Laboratory HWMF. 
Alternative 2 would reduce the mobility of chemical residuals in the basin because of the low permeability cap. Leaching of contaminants to groundwater would be significantly reduced at the basin, but the chemical residuals in the sediments surrounding the sewer line would have no reduction in mobility.

Alternative 3 would decrease the volume of the constituents in the basin, but the chemical residuals associated with the sewer line would remain in place.

Alternative 4 would reduce the mobility of the basin and sewer line sediment chemical residuals through the use of a low permeability cap.

Short-Term Effectiveness. Alternatives 1, 2, and 4 would pose little or no risk to on-site workers, the community, or the environment through exposure to the identified constituents. Twenty truck loads of hazardous material must be transported as part of Alternative 3. Exposure of workers, other SRS employees, and contractors to the hazardous materials may result from this transportation.

Estimated construction times for the alternatives are presented below:

\section{Alternative 1}

No Action

None

\section{Alternative 2}

No Waste Removal, No Action for Process Sewer Line, Basin Closure, and Evaluation of the Carolina Bay

4 Months

\section{Alternative 3}

Waste Removal, No Action for Process Sewer Line, Basin Closure, and Evaluation of the Carolina Bay 7 Months 


\section{Alternative 4}

No Waste Removal, Excavation of Process Sewer Line, Basin Closure, and Evaluation of the Carolina Bay

7 Months

Implementability. All of the proposed alternatives for the Metallurgical Laboratory HWMF would be easily implemented. However, Alternative 3 requires the transport of hazardous substances. There should be no problems in securing equipment and materials for the low permeability cap system, excavation of the process sewer line and associated sediments, or discharge of basin rainwater. Alternatives 2, 3 and 4 would require approval from SCDHEC for certain parts of the remedies, including the cap design and the receiving TSD facility.

Periodic inspection and, as necessary, repair of the low permeability cap would be required under Alternatives 2 and 4.

Cost. The originally estimated costs for all four alternatives include an annual O\&M cost of $\$ 20,000$ for a 30-year period for groundwater monitoring. These costs do not include monitoring beyond the 30 -year period potentially required to complete $\mathrm{A} / \mathrm{M}$ Area Groundwater remediation. The originally estimated present worth costs of each Alternative are presented below:

\section{Alternative 1}

No Action

$\$ 600,000$

\section{Alternative 2}

No Waste Removal, No Action for Process Sewer Line, Basin Closure, and Evaluation of the Carolina Bay

$\$ 1,600,000$

\section{Alternative 3}


Waste Removal, No Action for Process Sewer Line, Basin Closure, and Evaluation of the Carolina Bay

$\$ 1,600,000$

\section{Alternative 4}

No Waste Removal, Excavation of Process Sewer Line, Basin Closure, and Evaluation of the Carolina Bay

$\$ 2,000,000$

State Acceptance. SCDHEC has reviewed the closure plan and concurs with the preferred alternative, which is Alternative 4. Final approval will be made after public comments have been reviewed.

Community Acceptance. (To be addressed by DOE and EPA after the Proposed Plan public comment period.)

\section{Selected Remedy}

The preferred interim action alternative for the Metallurgical Laboratory HWMF Operable Unit is Alternative 4: No Waste Removal, Excavation of Process Sewer Line, Basin Closure, and Evaluation of the Carolina Bay. Alternative 4 includes no waste removal from the basin, excavation of process sewer line and associated contaminated sediments, basin closure with a low permeability soil cap, and evaluation of the Carolina Bay.

This alternative calls for the design and implementation of an interim remedial action to protect human health and the environment. The goal of the interim remedial action is to minimize migration to groundwater of the Metallurgical Laboratory Basin sediments associated with the process sewer line while risk assessment activities for the Carolina Bay are being planned and conducted. The ultimate goal of remediation will be determined in a final remedial action for this operable unit. Upon completion of the Carolina Bay risk 
assessment, this interim action may be incorporated into the design of the operable unit remedy specified in the final action $\mathrm{ROD}$.

\section{X . Path Forward}

Remedial actions regarding the Metallurgical Laboratory HWMF are currently being addressed as interim actions. "Path Forward" activities associated with this operable unit include a risk evaluation of the closed basin and sewer line area and a baseline risk assessment of the Carolina Bay. Upon completion of the risk evaluations, a final remedy will be selected.

\section{Statutory Determination}

The preferred alternative for the Metallurgical Laboratory HWMF is Alternative 4: No Waste Removal, Excavation of Process Sewer Line, Basin Closure, and Evaluation of the Carolina Bay. The remedy is protective of human health and the environment because it prevents physical exposure to contaminants by use of containment and institutional controls and mitigates further migration of contaminants to the groundwater by minimizing a liquid medium pathway (rainwater percolation) for transport.

Based on current information, Alternative 4 provides the best balance with respect to the nine criteria specified in the NCP. Although the interim action will not fully remediate the unit because the Carolina Bay has not been addressed, the action will result in disposal of basin rainwater, containment of basin and sewer line sediments and soils in a relatively small area beneath the cap of the basin, and therefore minimize migration of chemical residuals into the groundwater. Meanwhile, the investigation and risk assessment of the Carolina Bay will be reviewed. A final remedy for the unit will be selected following the risk assessment of the Bay, assuming that all ARARs have been satisfied. The final ROD 
for this operable unit will address the permanence of the final action and the preference for any treatment utilized in the final action to reduce the mobility, toxicity, and volume of hazardous substances. 


\section{Appendix A}

\section{References for Development of ROD Format}

Crane, Jeffrey L., 1992. "Working Meeting Notice for M-Area RODs, M-Area Groundwater, M-Area Settling Basin, Met Lab Basin," Letter to Chris Bergren (WSRC), U.S. Environmental Protection Agency, Region IV, Atlanta, GA, March $12,1992$.

EPA, 1989. "A Guide to Developing Superfund Records of Decision," OSWER Directive 9335.3-02FS-1, U.S. Environmental Protection Agency, Washington, D.C., November 1989.

EPA, 1991. "Guide to Developing Superfund No Action, Interim Action, and Contingency Remedy RODs," OSWER Publication 9355.3-02FS-3, U.S. Environmental Protection Agency, Washington, D.C., April 1991.

Longest, Henry L., and Bruce M. Diamond, 1990. "Suggested ROD Language for Various Groundwater Remediation Options," OSWER Directive 9283.1-03, U.S. Environmental Protection Agency, Washington, D.C., October 10, 1990.

WSRC, 1990. "RCRA Facility Investigation/Remedial Investigation Program Plan," WSRC-RP-89-994, Chapter 15, Westinghouse Savannah River Company, Aiken, South Carolina, September 1990. 
Appendix B

Responsiveness Summary

(No comments were received during the public review period) 